\title{
Táblaszegélyek szerepének vizsgálata a kisemlősök művelt területekre történő terjedésében
}

\author{
Bőti Szilvia*, Heltai Miklós, Márton Mihály \\ Szent István Egyetem, Mezőgazdaság- és Környezettudományi Kar, Vadvilág Megőrzési Intézet, \\ 2100 Gödöllő, Páter Károly utca 1.
}

\begin{abstract}
Study on the role of agricultural field edges in case the back spreading of small mammals in cultivated areas

Author(s): Szilvia Bőti, Miklós Heltai, Mihály Márton

Affiliation(s): Szent István University, Faculty of Agricultural and Environmental Sciences, Institute for Wildlife Conservation, H-2100 Páter Károly Street 1. Gödöllő, Hungary.

Rodents are important and common pests in the agricultural landscapes. During periodic gradations the small mammals cause considerable damages on both agricultural and forestry areas. The edges of agricultural fields could be the basis of gradation. The aim of our study we have looked for the answer that the edges which are different in type could be play a significant role in case the small mammals aggregation, and their back spreading in cultivated areas. The study areas are located in the northwestern part of Jász-Nagykun-Szolnok county, in the outer area of Jászfényszaru. The study was carried out between 28 February and 30 October 2016. In the first study area zero or few small mammal holes can be found. In case of edge the spatial pattern was primarily characterized by higher hole density in woody vegetation. In the second study area the hole density of small mammals showed different results in the table and in the edge, presumably due to the enrichment of the food supply and the disturbance (ploughing) of soil. In February in the first study area the habitat selection of small mammals was shown. They preferred the edge and avoided the arable stripe groups. In August in the second study area the small mammals have selected significantly between the stripe groups. They avoided the edge and preferred the middle of the field. The role of edge in the dispersion of small mammals to the agricultural area was not proved in the first study area, while in the second study area we received periodically different results.
\end{abstract}

Keywords: small mammals, dispersion, edge, preference

\section{ÖSSZEFOGLALÁS}

Az agrárökoszisztémákban közönséges rágcsálók a globális kártevők egyik legfontosabb csoportját képezik. Ezek a kisemlősök az időszakos gradációk alkalmával jelentős károkat okozhatnak a mezőgazdasági, és az erdészeti területeken. A gradáció kialakulását segíthetik a mezőgazdasági táblákat övező szegélyterületek is. Vizsgálatunkkal arra kerestünk választ, hogy van-e kimutatható szerepe a különböző típusú szegélyeknek a kisemlősök aggregálódásában, valamint azok művelt területekre történő

\footnotetext{
*CORRESPONDING AUTHOR
}

Szent István Egyetem, Mezőgazdaság- és Környezettudományi Kar, Vadvilág Megőrzési Intézet

2100 Gödöllö, Páter Károly utca 1.

E-mail: boti.szilvia@gmail.com 
visszaterjedésében. A vizsgálati területek Jász-Nagykun-Szolnok megye északnyugati részén, Jászfényszaru külterületén helyezkednek el. A felmérések 2016. február 28-tól október 30-ig történtek. Az első vizsgálati területen a táblán belül a felmérések alkalmával nulla vagy legfeljebb egy-két kisemlős lyuk volt fellelhető. A szegélyen belül a térbeli mintázatot elsősorban a fás szárú vegetációval rendelkező szegélyek magasabb lyuksűrűsége jellemezte. A második mintaterületen a kisemlős lyuksűrűség felmérésenként eltérő képet mutatott a szegélyben és a táblában, melyet feltehetően a táplálékkészlet feldúsulása és a talajbolygatás befolyásolt. A kisemlősök élőhelyválasztását az első vizsgálati területen február végén a szegély kifejezett preferenciája és a táblán belüli sáv csoportok erős elkerülése jellemezte. A második vizsgálati területen augusztusban volt kimutatható a kisemlősök válogatása a sáv csoportok között, a szegélyt elkerülték, míg a tábla közepét preferálták. A szegély szerepe a kisemlősök mezőgazdasági táblára történő terjedésében az első vizsgálati területen nem nyert bizonyítást, míg a második vizsgálati területen az időszakosan eltérő eredmények nem zárták ki a szegélyek terjedésben betöltött szerepét.

(Kulcsszavak: kisemlősök, terjedés, szegély, preferencia)

\section{BEVEZETÉS}

A mezőgazdasági termelés célja a szükséges termékeket megfelelő minőségben, állapotban és mennyiségben, alkalmas helyen és időben, költséghatékonyan rendelkezésre bocsátani (Kosztka 2010). A nagyüzemi mezőgazdaságban a minél nagyobb terméshozamok alacsony fajlagos költségek mellett a legegyszerűbben nagy és homogén táblák kialakításával érhetőek el (Heltai 2014). A mezőgazdaság intenzívebbé válása kedvez a jól alkalmazkodó, generalista fajoknak, míg a ritka és veszélyeztetett fajok gyakoribbak a hagyományos (kisparcellás, extenzív) mezőgazdasági ökoszisztémákban (De la Pena et al. 2003). A mezőgazdasági rendszerben a termelés hatékonyságára kockázatot jelentenek a különböző mezőgazdasági károk. Az agrárökoszisztémákban közönséges rágcsálók a globális kártevők egyik legfontosabb csoportját képezik (Jacob 2003, Stenseth et al. 2003). Világszerte körülbelül 1700 rágcsáló fajt ismerünk, de csak 5-10\%-uk okoz jelentős károkat a mezőgazdasági környezetben (Stenseth et al. 2003). A növénytermesztésben főként a mezei pocok (Microtus arvalis) jelenik meg károsítóként (Ivány et al. 1994, Aschwanden et al. 2007, Radics 2010). A 
gradáció kialakulását segíthetik a mezőgazdasági táblákat övező szegélyterületek is. Mivel a szegélyek jelentősége a különböző gazdasági ágazatok számára más és más (pl. kártevő és gyom rezervoár, fészkelő- és táplálkozóhely, biodiverzitás megőrzése), így annak kezelése esetenként teljes mértékben ellentétes lehet, amely számos konfliktushelyzetnek ad teret (Pinke 1999, Ángyán és Menyhért 2004, Faragó 2006).

Nem tisztázott, hogy a szegély, mint élőhely, milyen mértékben határozza meg a kisemlősök gyakoriságát, illetve szétszóródását, terjedését egy adott területen A tudásanyag bővítésével a rágcsálók elleni mezőgazdasági védekezés célzottabbá tehető, az időben és térben pontosabb kezelés következtében a haszon-ráfordítás mérleg kiegyenlítettebb lehet.

Tanulmányunkban vizsgáltuk, hogy van-e kimutatható szerepe a különböző típusú szegélyeknek a kisemlősök aggregálódásában, valamint azok művelt területekre történő visszaterjedésében.

\section{ANYAG ÉS MÓDSZER}

A vizsgálati területek Jász-Nagykun-Szolnok megye északnyugati részén, Jászfényszaru külterületén helyezkednek el.

Az első vizsgálati terület 46,7 hektár kiterjedésű, északi és déli oldalát akácos fasort követően földút, nyugati oldalát földutat követően akác-nyár erdő, keleti oldalát mezőgazdasági terület határolja (1. ábra). A vizsgálat ideje alatt a keleti oldalánál árpa (Hordeum vulgare), majd őszi búza (Triticum aestivum) alkotta a vegetációt. A vizsgálati terület táblájában a vizsgálati időszakban őszi káposztarepcét (Brassica napus) termesztettek, majd 2016 őszén búza került a táblába. A földhasználó elmondása alapján a területet 2013-ban járatkezelték mezei pocok ellen.

A második vizsgálati terület 2,8 hektár kiterjedésű, északi oldalát földút, azt követően füves sáv, déli, nyugati és keleti oldalát mezőgazdasági tábla határolja. A vizsgálat ideje alatt a déli oldalnál búza, majd gabonavetés, a nyugati oldalnál rövidebb ideig kukorica (Zea mays), majd szántás volt. A keleti oldalon délről indulva kisebb szakaszon (11 m-en) gyep, 92 m-en rozs (Secale cereale), 120 m-en többéves lucerna (Medicago sativa), 85 m-en szántás, majd 2016 szeptemberétől lucerna, 12 m-en keresztül pedig kukorica volt (2. ábra). A vizsgálati terület táblájában őszi búzát termesztettek, majd a betakarítását követően a területet felszántották. 
A kisemlős állománysűrűség felmérését és monitorozását lyuksűrűség becsléssel végeztük (Lisická et al. 2007, Márton és Heltai 2015). Az adatgyűjtés az első vizsgálati területen négy alkalommal történt (2016. február 28., április 02-03., július 07-08., október 30.). A júliusi mérésnél csak a tábla került felmérésre, a szegély a magas lágyszárú vegetáció sűrű borítása következtében nem. A második vizsgálati területen öt alkalommal történt adatgyüjtés (2016. március 12., április 03., május 09., augusztus 13., október 30.). A két mintavételi terület külön-külön került elemzésre, összehasonlításuk nem volt lehetséges.

A kisemlős lyukak felvételezése sávos becsléssel történt, egy-egy sáv szélessége 2 méter volt (Márton et al. 2014). A sávokat 50 méteres szakaszokra osztottuk (ettől rövidebbek csak a sávok végén elhelyezkedő szakaszok voltak). A szegélyekben két-két, oldalanként elkülönülő sáv, míg a táblák belsejében az első vizsgálati területen hat, a második vizsgálati területen öt, az oldalakkal párhuzamosan futó, egybefüggő, a tábla alakját követő sáv helyezkedett el. A sávok egymáshoz képest a szegélyekben 5 méterre, a táblákban az eltérő alak és méret miatt az első mintaterületen 50 méterre, a második mintaterületen 10 méterre húzódtak.

A statisztikai értékelés alapegységét adó kisemlős lyuksűrűséget db/100 $\mathrm{m}^{2}$ mértékegységben adtuk meg. Az első vizsgálati területen a szegélyeket, valamint az 1-es és 2-es, 3-as és 4-es, 5-ös és 6-os tábla sávokat egyben kezeltük, így alakult ki négy csoport, melyeket a következő jelölésekkel láttuk el: szegély (szegélysávok), tábla szél (1-es, 2-es sáv), tábla közép (3-as, 4-es sáv) és tábla belső (5-ös, 6-os sáv). A második vizsgálati területen is négy csoportot alakítottunk ki: szegélyt (szegélysávok), tábla szélt (1-es és 2-es sáv), tábla közepet (3-as és 4-es sáv) és tábla belsőt (5-ös sáv). Az adatsorokon belül a normál eloszlás teszteléséhez Kolmogorov-Smirnov tesztet alkalmaztunk (Reiczigel et al. 2010). A térbeli elemzést (egyes sávok lyuksűrűségének egymáshoz viszonyítását) mérésenként Kruskal-Wallis teszttel, és Dunn-féle post hoc próbával végeztük. Az időbeli változás vizsgálatához (ugyanazon sávok lyuksűrűségének mérésenkénti összevetéséhez) Friedman tesztet és Dunn-féle post hoc próbát alkalmaztunk (Reiczigel et al. 2010). 


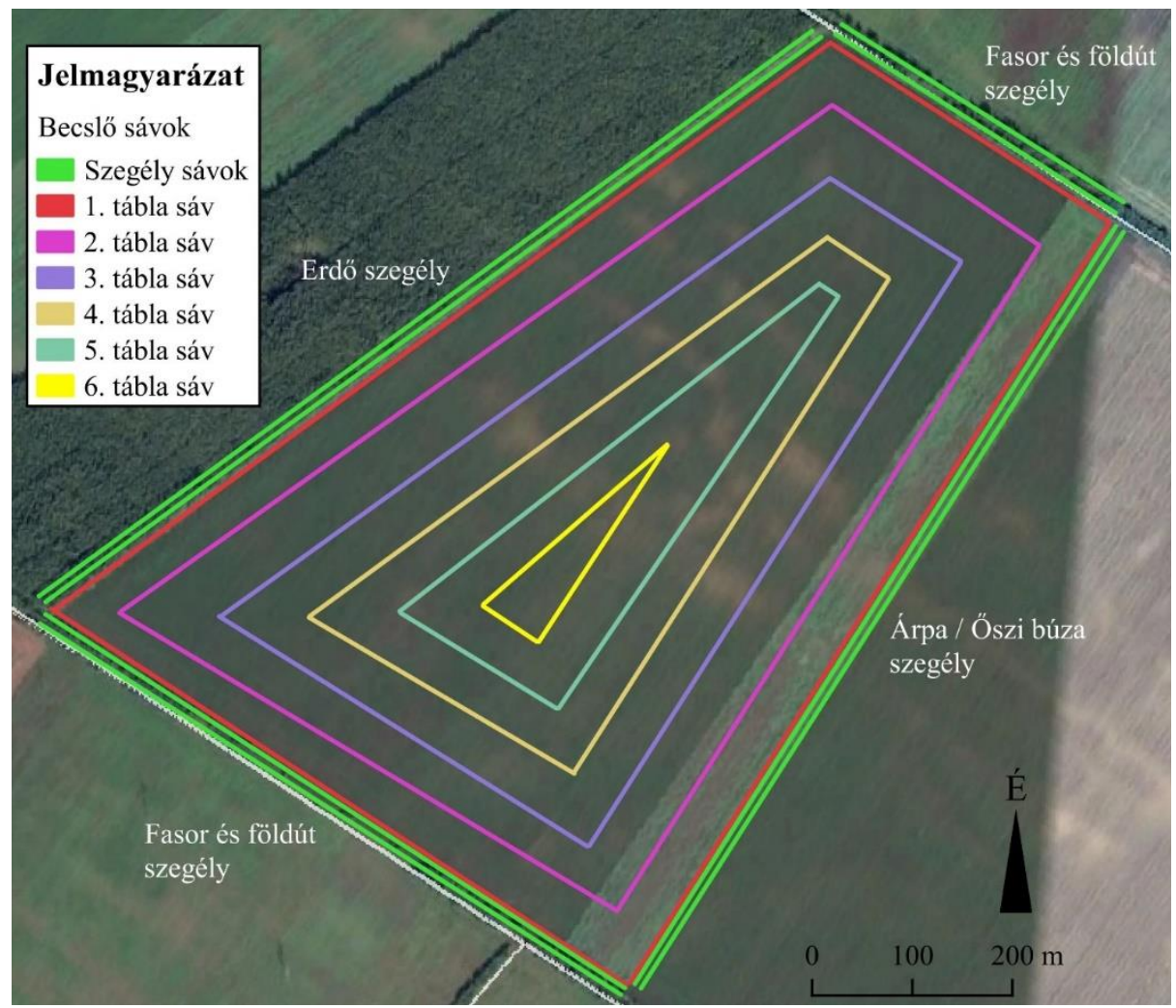

1. ábra. Az első vizsgálati terület szegélyeinek és becslő sávjainak áttekintő ábrázolása

Figure 1: Overview of estimation stripes and edges in case of the first study area

A kisemlősök élőhelyválasztásának vizsgálata során a válogatást kétféle módon teszteltük. Első esetben a megtalált kisemlős lyukak eloszlását a fentebb ismertetett sávcsoportok területi aránya alapján várható eloszlással vetettük össze. A második esetben a megtalált kisemlős lyukak eloszlását a Quantum GIS 2.18.2 térinformatikai programban generált véletlen pontok eloszlásával hasonlítottuk össze. A véletlen pontok elemszáma megegyezett az adatgyűjtés során feljegyzett kisemlős lyukak számával. Utóbbi módszert öt alkalommal ismételtük. 


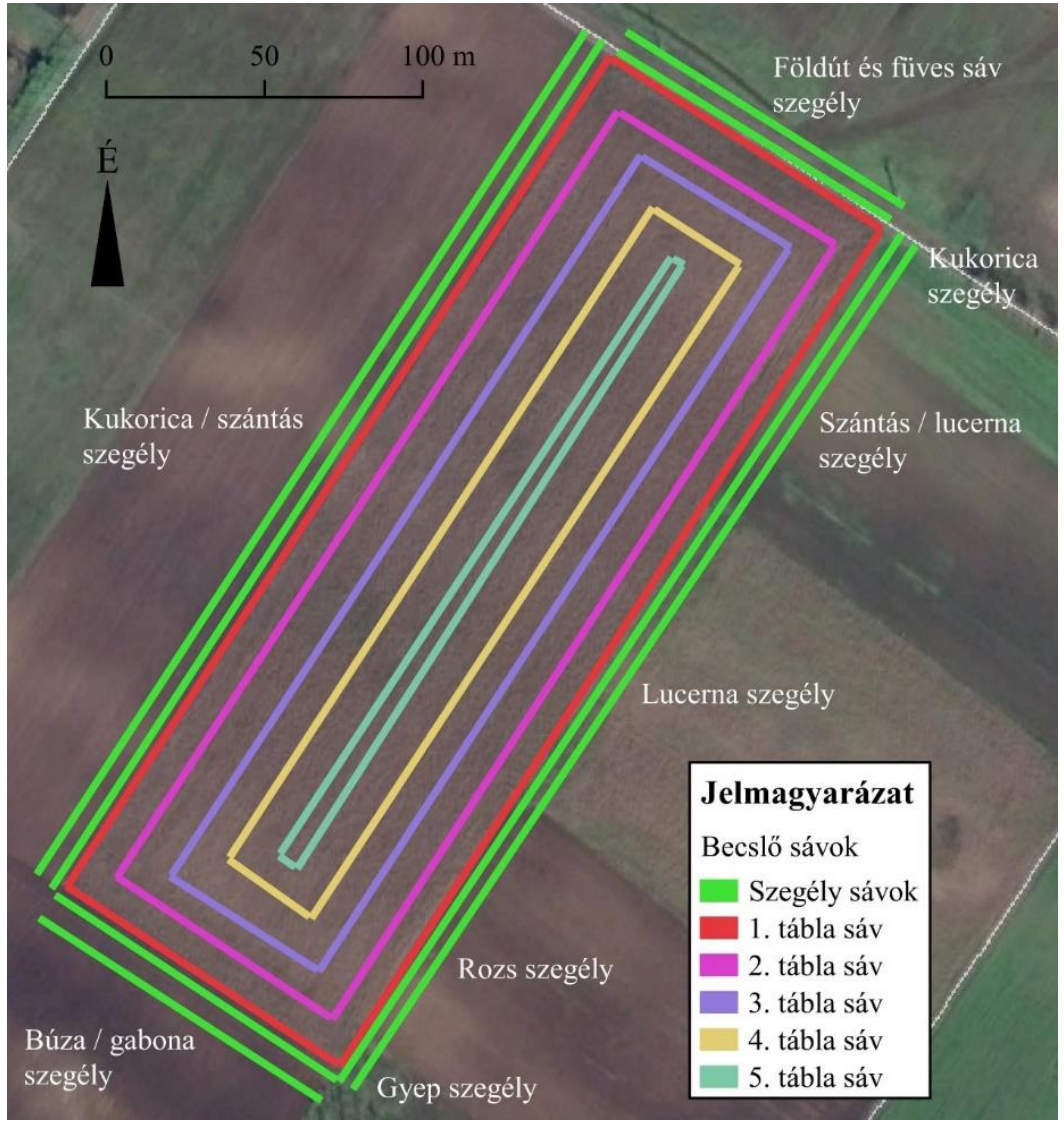

2. ábra. A második vizsgálati terület szegélyeinek és becslő sávjainak áttekintő ábrázolása

Figure 2: Overview of estimation stripes and edges in case of the second study area

Az első mintaterületen a február végi eredmények tették lehetővé a számítás elvégzését, míg a második mintaterületen a március eleji és az augusztusi mérés. Ennek oka az év későbbi szakaszában fellépő vegetációs torzítás, valamint a talajbolygatás volt. Az eloszlásokat Fisher-féle egzakt próbával teszteltük (Fisher 1922). Továbbá a véletlen eloszlások esetében Bonferroni Zteszttel sávcsoportonként elemeztük az eloszlásban való eltérést (Byers et al. 
1984). A válogatás tesztelését követően az élőhelypreferenciát Bonferroni Zteszttel és Jacobs-indexszel (Jacobs 1974) számítottuk ki.

A terjedés tesztelése a mintaszám és a lyukak területi eloszlásának függvényében kizárólag a második vizsgálati területen a márciusi és az augusztusi méréseknél volt lehetséges, melyet Fisher-féle egzakt próbával vizsgáltunk (Fisher 1922). Az elemzés alapját az összes oldalankénti kisemlős lyuk darabszám adta.

\section{EREDMÉNYEK ÉS ÉRTÉKELÉS}

\section{Első vizsgálati terület}

Az első vizsgálati területen a táblán belül a mérések alkalmával nulla vagy legfeljebb egy-két kisemlős lyuk volt fellelhető, a szegély azonban már változatosabb képet mutatott (1. táblázat).

\section{1. táblázat}

Az első vizsgálati terület felméréseinek leíró statisztikai eredményei (Jászfényszaru)

\begin{tabular}{lcccccc}
\hline \multirow{2}{*}{$\begin{array}{c}\text { Első vizsgálati } \\
\text { terület }\end{array}$} & \multicolumn{5}{c}{ Lyuksűrűség $\left(\mathrm{db} / 100 \mathrm{~m}^{2}\right)^{2}$} & Összes talált \\
\cline { 3 - 6 } & & Átlag $^{3}$ & Szórás $^{4}$ & $\begin{array}{c}\text { Minimum } \\
\text { érték }^{5}\end{array}$ & $\begin{array}{c}\text { Maximum } \\
\text { érték }^{6}\end{array}$ & \\
\hline \multirow{2}{*}{ Február8 $^{8}$} & $\mathrm{Sz}$ & 1,97 & 3,80 & 0 & 26 & 226 \\
& $\mathrm{~T}$ & 0,01 & 0,20 & 0 & 3 & 3 \\
Április $^{9}$ & $\mathrm{Sz}$ & 0,35 & 0,98 & 0 & 6 & 40 \\
& $\mathrm{~T}$ & 0,00 & 0,07 & 0 & 1 & 1 \\
Július $^{10}$ & $\mathrm{Sz}$ & - & - & - & - & - \\
& $\mathrm{T}$ & 0,02 & 0,17 & 0 & 2,38 & 2 \\
Október $^{11}$ & $\mathrm{Sz}$ & 0,56 & 1,23 & 0 & 6,25 & 63 \\
& $\mathrm{~T}$ & 0,00 & 0,00 & 0 & 0 & 0 \\
\hline
\end{tabular}

Megjegyzés: Sz= szegély, T= tábla

Table 1: Descriptive statistical results based on the measurement of the first study area (Jászfényszaru) The first study area(1), Hole density (piece $\left./ 100 \mathrm{~m}^{2}\right)(2)$, Average(3), Standard deviation(4), Minimum value(5), Maximum value(6), The total number of holes(7), February(8), April(9), July(10), October(11); Note: $S z=$ edge, $T=$ field

A szegélyen belül a mérések átlagában a legnagyobb lyuksűrűség a fás útszéleken, és az erdő északi felében volt megfigyelhető, a legkisebb sűrűség érték pedig az árpa tábla szegélyénél. A február és október végi méréseknél a szegélyben a gócpontok megközelítőleg ugyanott helyezkedtek el. Az októberi 
mérésnél lényegesen kevesebb kisemlős lyukat észleltünk, mint a februári mérés alkalmával, amihez hozzájárult az őszi magas vegetáció is, mely a megfigyelési valószínűségek feltehető eltérését okozta.

Az áprilisi mérésnél a szegélyben a magas lágyszárú növényzet miatt rossz észlelési viszonyok voltak, ezért a júliusi mérésnél a szegély már nem került felmérésre. Áprilisban a táblában csak 1 db lyuk került feljegyzésre, júliusban összesen $2 \mathrm{db}$, az is a tábla széleken.

Térben elemezve a vizsgálati területet, az első (februári) mérés alkalmával a Kruskal-Wallis teszt és a Dunn-féle post hoc próba szignifikáns különbséget (KW=110,02; $p<0,001 ; n=347)$ mutatott a szegély és a tábla szél (Dunn próba: $\mathrm{p}<0,001$ ), a szegély és a tábla közép (Dunn próba: $\mathrm{p}<0,001$ ), valamint a szegély és a tábla belső (Dunn próba: $\mathrm{p}<0,001$ ) között. Április elején szintén ezt az eredményt tapasztaltuk $(\mathrm{KW}=38,9 ; \mathrm{p}<0,001 ; \mathrm{n}=347$; Dunn próba: szegély-tábla szél $p<0,001$, szegély-tábla közép $p<0,001$, szegély-tábla belső $\mathrm{p}<0,001)$. Július elején nem volt szignifikáns különbség a tábla sávok között (KW= 2,101; $\mathrm{p}=0,350 ; \mathrm{n}=223$ ), a szegélyt ekkor nem lehetett felmérni. Az október végi mérésnél ismét jelentős eltérést ( $K W=64,65 ; p<0,001 ; n=347$ ) mutatott a szegély és a tábla szél (Dunn próba: $p<0,001$ ), a szegély és a tábla közép (Dunn próba: $\mathrm{p}<0,001$ ), illetve a szegély és a tábla belső (Dunn próba: $\mathrm{p}<0,001$ ) is.

$\mathrm{Az}$ egyes mérési időpontok eredményeit összevetve a szegélynél szignifikáns különbség jelentkezett a februári és az áprilisi mérés ( $\mathrm{Fr}=44,274$; $\mathrm{p}<0,0001 ; \mathrm{n}=348$; Dunn próba: $\mathrm{p}<0,001$ ), illetve a februári és az októberi mérés (Dunn próba: $\mathrm{p}<0,01)$ alkalmával. A tábla szél $(\mathrm{Fr}=3,667 ; \mathrm{p}=0,300 ; \mathrm{n}=$ 436) és a tábla közép ( $F r=3 ; p=0,392 ; n=304)$ időben vizsgálva sem mutatott eltérést. A tábla belsőben egyik mérés alkalmával sem találtunk kisemlős lyukat, így a Friedman tesztet és a Dunn-féle post hoc próbát nem lehetett rá elvégezni.

\section{Második vizsgálati terület}

A második vizsgálati területen a szegélyben és a táblában is változó sűrűséggel fordult elő kisemlős lyuk, melyet mérésenként az átlagos lyuksűrűség fluktuációja is mutat (2. táblázat).

Három szegélynél nem találtunk kisemlős lyukat a mérések alkalmával, ezek a szomszédos búza- és a kukoricatáblákkal érintkező, valamint a földút menti szegélyek. 
A március eleji felmérésnél még koncentráltan fordultak elő a kisemlős lyukak, a legnagyobb sűrűség a gyep szegélyében volt.

\section{2. táblázat}

A második vizsgálati terület felméréseinek leíró statisztikai eredményei (Jászfényszaru)

\begin{tabular}{|c|c|c|c|c|c|c|}
\hline \multirow{2}{*}{\multicolumn{2}{|c|}{ Második vizsgálati terület ${ }^{1}$}} & \multicolumn{4}{|c|}{ Lyuksűrűség (db/100 m²)2 } & \multirow{2}{*}{$\begin{array}{l}\text { Összes talált } \\
\text { lyukak } \\
\text { száma7 }^{7}\end{array}$} \\
\hline & & Átlag3 & Szórás ${ }^{4}$ & $\begin{array}{l}\text { Minimum } \\
\text { érték }{ }^{5}\end{array}$ & $\begin{array}{c}\text { Maximum } \\
\text { érték }^{6}\end{array}$ & \\
\hline \multirow{2}{*}{ Március ${ }^{8}$} & $\mathrm{Sz}$ & 0,30 & 1,02 & 0 & 6 & 12 \\
\hline & $\mathrm{T}$ & 0,23 & 0,80 & 0 & 4 & 14 \\
\hline \multirow{2}{*}{ Április ${ }^{9}$} & $\mathrm{Sz}$ & 0,15 & 0,66 & 0 & 4 & 6 \\
\hline & $\mathrm{T}$ & 0,17 & 0,51 & 0 & 2 & 13 \\
\hline \multirow{2}{*}{ Május ${ }^{10}$} & $\mathrm{Sz}$ & 0,00 & 0,00 & 0 & 0 & 0 \\
\hline & $\mathrm{T}$ & 0,07 & 0,34 & 0 & 2 & 5 \\
\hline \multirow{2}{*}{ Augusztus ${ }^{11}$} & $\mathrm{Sz}$ & 0,05 & 0,32 & 0 & 2 & 2 \\
\hline & $\mathrm{T}$ & 0,48 & 1,04 & 0 & 5 & 31 \\
\hline \multirow{2}{*}{ Október ${ }^{12}$} & $\mathrm{Sz}$ & 0,55 & 2,00 & 0 & 12 & 22 \\
\hline & $\mathrm{T}$ & 0,00 & 0,00 & 0 & 0 & 0 \\
\hline
\end{tabular}

Megjegyzés: Sz= szegély, T= tábla

Table 2: Descriptive statistical results based on the measurement of the second study area (Jászényszaru) The second study area(1), Hole density (piece/100 m²)(2), Average(3), Standard deviation(4), Minimum value(5), Maximum value(6), The total number of holes(7), March(8), April(9), May(10), August(11), October(12);Note: $\mathrm{Sz}=$ edge, $T=$ field

$\mathrm{Az}$ áprilisi és májusi felméréseknél szórványos mintázatú, alacsony lyuksűrűség mutatkozott. Az áprilisi felmérésnél a táblában talált lyukak elhelyezkedésében a következőket figyeltük meg: több lyuk (6 db) környezetében a tábla összképére jellemzőnél erőteljesebb volt a gyomosodás vagy egy-egy sűrűbb búza foltban helyezkedett el, néhány lyuk (2 db) közvetlen közelében kukoricaszem vagy kukoricacső maradványt (elővetemény) találtunk. A májusi mérésnél a búza már $50-80 \mathrm{~cm}$ magas volt, ez gyengíthette az észlelés hatékonyságát.

Az augusztusi mérésnél a szegélyben a magasabb növényzet miatt néhol gyenge volt az észlelhetőség, a táblában azonban minden sávon volt kisemlős lyuk. A mérések alkalmával augusztusban volt a legtöbb kisemlős lyuk, mely felmérés a búza aratása után egy nappal történt. Az októberi mérésnél csak a szegélyben találtunk kisemlős lyukat (lucerna táblák, füves sáv). A vizsgált búzatábla ekkor már szántott állapotban volt. 
A térbeli összehasonlítás esetében a március eleji mérésnél a KruskalWallis teszt és a Dunn-féle post hoc próba nem mutatott szignifikáns különbséget a sávok között ( $\mathrm{KW}=2,661 ; \mathrm{p}=0,447 ; \mathrm{n}=116)$, csakúgy, mint az áprilisi mérés alkalmával $(K W=3,402 ; p=0,33 ; n=116)$. A májusi $(K W=9,594$; $\mathrm{p}=0,022 ; \mathrm{n}=116$ ) és az augusztusi mérésnél (KW=10,523; $\mathrm{p}=0,015 ; \mathrm{n}=116)$ szignifikáns különbség mutatkozott a szegély és a tábla közép között (Dunn próba: $\mathrm{p}<0,05)$. Az októberi mérésnél a szegély és a tábla szél között jelentkezett szignifikáns különbség (KW=10,011; $\mathrm{p}=0,019 ; \mathrm{n}=116$; Dunn próba: $\mathrm{p}<0,05$ ).

Időben vizsgálva a szegély lyuksűrűsége a Friedman teszt ( $\mathrm{Fr}=13,007$; $\mathrm{p}=$ 0,011; $n=200$ ) alapján szignifikáns különbséget mutatott, de ezt a Dunn-féle post hoc próba nem támasztotta alá. A tábla szélnél $(\mathrm{Fr}=10,667 ; \mathrm{p}=0,031 ; \mathrm{n}=$ 180) és a tábla belsőnél $(F r=16 ; p=0,003 ; n=60)$ is csak a Friedman teszt alapján volt szignifikáns a különbség, a Dunn-féle post hoc próba ezt nem erősítette meg. A tábla közép időbeli vizsgálata sem mutatott statisztikailag igazolható különbséget ( $F r=8,846 ; p=0,065 ; n=140)$.

\section{Élőhelyválasztás}

Az első mintaterületen február végén a sávtípusok alapján történő válogatás a sávtípusok arányán alapuló módszer (Fisher: $\mathrm{p}<0,001 ; \mathrm{n}=229$ ) és a véletlen pontok eloszlása alapján is kimutatható volt (minden esetben: Fisher: $\mathrm{p}<$ 0,$001 ; n=229$ ). A kisemlősök a szegélyre kifejezett preferenciát mutattak, míg erős elkerülés jellemezte a tábla szélt, a tábla közepet és a tábla belsőt ( 3 . táblázat).

A második mintaterületen március elején a sávtípusok alapján nem volt statisztikailag igazolható a válogatás (Fisher: $p=0,479 ; n=26$ ). Ezzel egyező eredményt kaptunk a véletlen pontok eloszlásán alapuló módszer esetében is (minden esetben Fisher: $\mathrm{p} \geq 0,05$ ). Augusztusban a válogatás a sávok területi aránya (Fisher: $\mathrm{p}=0,019 ; \mathrm{n}=33$ ) és a véletlen pontok eloszlása (minden esetben: Fisher: $\mathrm{p}<0,05 ; \mathrm{n}=33$ ) alapján is szignifikánsnak bizonyult. A talált lyukak és a véletlen pontok eloszlása között a Bonferroni Z-teszt a szegély és a tábla közép esetében mutatott statisztikailag igazolható eltérést (3. táblázat).

A preferencia értékeket tekintve az első vizsgálati területen a szegélyt preferálták a kisemlősök, míg a táblasávokat elkerülés jellemezte. A második mintaterületen a szegélyt elkerülték a kisemlősök, míg a tábla közepét preferálták. A tábla szélre és a tábla belsejére az elkerülés, illetve a preferencia nem volt statisztikailag igazolható (4. táblázat). 


\section{3. táblázat}

A kisemlős lyukak eloszlása az első és a második vizsgálati területen (Jászfényszarun) a véletlen pontok eloszlásával összehasonlítva

\begin{tabular}{|c|c|c|c|c|c|c|c|c|c|c|c|c|}
\hline \multirow{3}{*}{$\begin{array}{c}\text { Sáv } \\
\text { csoport }^{1}\end{array}$} & \multicolumn{6}{|c|}{ Első vizsgálati terület ${ }^{2}$} & \multicolumn{6}{|c|}{ Második vizsgálati terület ${ }^{3}$} \\
\hline & \multicolumn{6}{|c|}{ Február 4} & \multicolumn{6}{|c|}{ Augusztus $^{5}$} \\
\hline & $\begin{array}{c}\text { Talált lyuk } \\
(\mathrm{db})^{6}\end{array}$ & $\begin{array}{c}\mathrm{VE} \\
1\end{array}$ & $\begin{array}{c}\mathrm{VE} \\
2 \\
\end{array}$ & $\begin{array}{c}\mathrm{VE} \\
3 \\
\end{array}$ & $\begin{array}{c}\text { VE } \\
4 \\
\end{array}$ & $\begin{array}{c}\mathrm{VE} \\
5\end{array}$ & $\begin{array}{c}\text { Talált lyuk } \\
(\mathrm{db})^{7}\end{array}$ & $\begin{array}{c}\mathrm{VE} \\
1\end{array}$ & $\begin{array}{l}\mathrm{VE} \\
2 \\
\end{array}$ & $\begin{array}{c}\mathrm{VE} \\
3 \\
\end{array}$ & $\begin{array}{c}\mathrm{VE} \\
4 \\
\end{array}$ & $\begin{array}{c}\text { VE } \\
5\end{array}$ \\
\hline Szegély 8 & 226 & $* * *$ & $* * *$ & $* * *$ & $* * *$ & $* * *$ & 2 & ** & *** & $* * *$ & $* * *$ & $* * *$ \\
\hline Tál & 0 & $* * *$ & $* * *$ & $* * *$ & $* * *$ & $* * *$ & 10 & ns. & ns. & ns. & ns. & ns. \\
\hline $\begin{array}{l}\text { Tábla } \\
\text { közép } 10\end{array}$ & 3 & $* * *$ & $* * *$ & $* * *$ & *** & $* * *$ & 17 & ** & *** & ns. & *** & ** \\
\hline $\begin{array}{l}\text { Tábla } \\
\text { belső"11 }\end{array}$ & 0 & $* * *$ & $* * *$ & $* * *$ & *** & $* * *$ & 4 & ns. & ns. & ns. & ns. & ns. \\
\hline
\end{tabular}

Megjegyzés: Bonferroni Z-teszt: ${ }^{* *}=\mathrm{p}<0,01{ }^{* * *}=\mathrm{p}<0,001$; ns.= nem szignifikáns; VE= véletlen eloszlás

Table 3: Distribution of small mammal holes on the two study areas (in Jászfényszaru) comparing to the distribution of the random points. Stripe group(1), The first study area(2), The second study area(3), February(4), August(5), The measured number of holes (piece)(6), The measured number of holes (piece)(7), Edge(8), Field side(9), Middle of field(10), Inside of field(11); Note: Bonferroni Z-test: ${ }^{* *}=p<$ 0,$01 ;{ }^{* * *}=p<0,001 ; n s .=$ not significant; $V E=$ random distribution

\section{4. táblázat}

A kisemlősök élőhelyválasztása az első és a második vizsgálati területen (Jászfényszarun) a különböző felmérések időpontjában

\begin{tabular}{|c|c|c|c|c|c|c|}
\hline \multirow{3}{*}{$\begin{array}{c}\text { Sáv } \\
\text { csoport }^{1}\end{array}$} & \multirow{2}{*}{\multicolumn{2}{|c|}{$\begin{array}{c}\text { Első vizsgálati terület }^{2} \\
\text { Február }^{4}\end{array}$}} & \multicolumn{4}{|c|}{ Második vizsgálati terület ${ }^{3}$} \\
\hline & & & \multicolumn{2}{|c|}{ Március 5} & \multicolumn{2}{|c|}{ Augusztus $^{6}$} \\
\hline & $\begin{array}{l}\text { Jacobs- } \\
\text { index }^{7}\end{array}$ & $\begin{array}{c}\text { Bonferroni } \\
\text { Z-teszt }{ }^{8} \\
\end{array}$ & $\begin{array}{l}\text { Jacobs- } \\
\text { index }^{9}\end{array}$ & $\begin{array}{c}\text { Bonferroni } \\
\text { Z-teszt }{ }^{10}\end{array}$ & $\begin{array}{l}\text { Jacobs- } \\
\text { index }{ }^{11}\end{array}$ & $\begin{array}{c}\text { Bonferroni } \\
\text { Z-teszt }{ }^{12}\end{array}$ \\
\hline Szegély 13 & 0,99 & $*$ & - & - & $-0,78$ & $*$ \\
\hline Tábla szél14 & $-1,00$ & $*$ & - & - & $-0,04$ & ns. \\
\hline $\begin{array}{l}\text { Tábla } \\
\text { közép } 15\end{array}$ & $-0,91$ & $*$ & - & - & 0,53 & $*$ \\
\hline $\begin{array}{l}\text { Tábla } \\
\text { belső}^{16}\end{array}$ & $-1,00$ & $*$ & - & - & 0,14 & ns. \\
\hline
\end{tabular}

Megjegyzés: Bonferroni Z-teszt: ${ }^{*}=\mathrm{p}<0,05 ;$ ns. $=$ nem szignifikáns

Table 4: Habitat selection of small mammals on the two study areas (in Jászfényszaru) at the time of the various measurements. Stripe group(1), The first study area(2), The second study area(3), February(4), March(5), August(6), Jacobs-index(7), Bonferroni Z-test(8), Jacobs-index(9), Bonferroni Z-test(10), Jacobs-index(11), Bonferroni Z-test(12), Edge(13), Field side(14), Middle of field(15), Inside of field(16); Note: Bonferroni Z-test; ${ }^{*}=p<0,05 ;$ ns. $=$ not significant 


\section{Terjedés}

A terjedést a második mintaterületen a márciusi és az augusztusi mérés esetében vizsgáltuk, melyet sávonként végeztünk el. A márciusi mérés elemzése során a szegély és a tábla sávok között többnyire nem volt statisztikailag igazolható különbség (1-es sáv: $\mathrm{p}=0,154 ; \mathrm{n}=13 ; 3$-as sáv: $\mathrm{p}=$ 1,00; $\mathrm{n}=12 ; 4$-es sáv: $\mathrm{p}=0,066 ; \mathrm{n}=14 ; 5$-ös sáv: $\mathrm{p}=1,00 ; \mathrm{n}=12$ ). A második sávval összevetve azonban szignifikáns a különbség $(\mathrm{p}=0,011 ; \mathrm{n}=17)$. Az augusztusi mérés esetében a márciusi szegély és az augusztusi tábla sávok összevetésénél nem kaptunk szignifikáns különbséget (1-es sáv: p= 0,062; n= 20; 2 -es sáv: $\mathrm{p}=0,109 ; \mathrm{n}=14 ; 3$-as sáv: $\mathrm{p}=1,00 ; \mathrm{n}=22 ; 4$-es sáv: $\mathrm{p}=0,446 ; \mathrm{n}=$ 27; 5-ös sáv: $p=0,637 ; n=16$ ).

\section{KÖVETKEZTETÉSEK}

A vizsgálat során térben és időben az első mintaterületen nagy változatosságot lehetett tapasztalni a kisemlős lyuksűrűségben. A mérések során szinte kizárólag a szegélyben kerültek feljegyzésre kisemlős lyukak. A szegélyen belül a térbeli mintázatot elsősorban a fás szárú vegetációval rendelkező szegélyek magasabb lyuksűrüsége jellemezte, az árpával vetett szegélyben (keleti oldal) az első vizsgálati terület tábláját borító repcét megközelítő, alacsony sűrűséget tapasztaltunk. A táblában mért kisemlős lyuksűrüség az egyes mérési időszakokban stabilan alacsony volt, míg a szegélyben mért denzitás erősen fluktuált. Egy börzsönyi vizsgálat (Márton et al. 2014) során hasonló eredményt tapasztaltak, ahol negatív kapcsolat volt kimutatható a nyílt területek aránya és a kisemlős lyuksűrűség között. Ott a nyílt területet több mint 50 \%-ban mezőgazdaságilag művelt területek alkották, míg a kisebbik hányad kaszáló volt. Egy másik börzsönyi tanulmány (Márton és Heltai 2016) az erdő-mezőgazdasági terület élőhelyegyüttes kisemlős faunáját vizsgálta, melynek során a tölgyerdővel szomszédos repcetáblában októbertől augusztusig nem sikerült kisemlőst kimutatni. A vizsgálatunk során kétséget kizáróan nem jelenthető ki, hogy az első mintaterületen a szegélyben talált magasabb kisemlős lyuksűrűség az ökológiai értelemben vett szegélyhatás következménye, okozhatta ezt az is, hogy a bolygatatlan talajú, az év nagy részében takarást és táplálékot nyújtó fás, cserjés vegetáció jobb élőhelyet jelent a kisemlősöknek, mint a művelt terület. Több külföldi vizsgálat során kimutatták, hogy a mezőgazdasági táblát övező, erdő alkotta szegélyzóna, valamint az erdő belseje között a kisemlős faj- és egyedszámban nincs 
statisztikailag alátámasztható különbség (Heske 1995, Sekgororoane és Dilworth 1995, Bayne és Hobson 1998).

A második mintaterületen a tavasz első felében a szegélyben és a táblában nagyságrendileg azonos mértékben találtunk kisemlős lyukakat. Májusban és augusztusban a kisemlős lyuksürűség kimutathatóan magasabb volt a tábla középső sávjában, mint a szegélyben. Ez feltehetően a nagyobb mértékű takarás és a feldúsult táplálékkészlet együttes jelenlétével magyarázható (Lagos et al. 1995, Klein 2007, Márton és Heltai 2016). Egy dél-ausztráliai vizsgálatban a házi egér (Mus musculus) egyedek területi eloszlása a tavaszi és a nyári időszakban közel egyező képet mutatott az általunk talált kisemlős lyuksűrűség területi és időbeli mintázatával (Newsome 1969). Októberben a szegélyben statisztikailag igazolhatóan magasabb volt a lyuksűrűség, mint a tábla szélső sávjában. A mintavétel során a tábla szélhez hasonlóan a tábla közép és a belső sáv csoportjában sem találtunk kisemlős lyukat. Az, hogy e sávcsoportok lyuksűrűségénél a szegély lyuksűrűsége miért nem magasabb statisztikailag igazolhatóan, az a tábla belseje felé haladva egyre csökkenő mintavételi szakasz darabszámmal magyarázható (Reiczigel et al. 2010). A kisemlős lyukak tábláról való közel teljes eltúnésének hátterében egy általánosan alkalmazott agrotechnikai lépés, az őszi szántás állhat (Németh 2014).

Az első vizsgálati területen a kisemlősök élőhelyválasztását február végén a szegély kifejezett preferenciája és a táblán belüli sáv csoportok erős elkerülése jellemezte. Ez a preferencia feltételezhetően a repce júliusi betakarításáig megmaradhatott. Ekkor a táblában nagyon alacsony sürűségben találtunk kisemlős lyukat, azonban a szegély felmérése a magas és dús vegetáció miatt nem volt lehetséges. A szegély preferenciája felhívja a figyelmet a nagyobb kiterjedésű táblákat ( $\geq 50$ ha) körülvevő fás és cserjés határvegetációk fontosságára a kisemlős életközösségek szempontjából (Silva et al. 2005, Németh 2014). A második vizsgálati területen március elején nem volt kimutatható a kisemlősök válogatása a sáv csoportok között, azokat területi kínálatuknak megfelelő arányban használták. Augusztusban a válogatás kimutatható volt, a szegélyt kerülték a kisemlősök, míg a tábla középső része preferált volt. A tábla szél és a tábla belső sáv csoport esetében szignifikáns elkerülés, vagy preferencia nem volt kimutatható, azokat területi arányuknak megfelelően használták a kisemlősök. Márton és Heltai (2016) betakarítás előtt álló tavaszi árpában tapasztalt hasonló élőhelyválasztást, melyet a megnövekedett táplálékkínálattal magyaráztak. 
A szegélynek a kisemlősök mezőgazdasági táblára történő terjedésében betöltött szerepét vizsgálva elmondható, hogy a szegélyeknek ez a növénytermesztési szempontból negatív funkciója az első vizsgálati területen nem nyert bizonyítást, melyet a mérések során a táblában tapasztalt kifejezetten alacsony lyuksűrűség támaszt alá. A második vizsgálati területen a mintaszámok a márciusi és az augusztusi mérés esetében tették lehetővé a terjedés elemzését. A márciusi mérésnél a szegély és a táblasávok között többnyire nem volt szignifikáns különbség, ez azonban inkább az oldalankénti alacsony mintaszámnak tudható be. A legmagasabb mintaszámmal rendelkező táblasáv esetében (2. sáv: $n=17$ ) szignifikáns volt a különbség, amely a szegély terjedésben betöltött szerepét nem erősíti meg. Az augusztusi mérés esetében nem kaptunk szignifikáns különbséget a márciusi szegély és az augusztusi táblasávok között, ennek egy része az alacsony mintaszámnak tudható be, két esetben azonban a mintaszám is elegendően magas (3. sáv: $n=22$, 4. sáv: $n=$ 27), így ez az eredmény a szegély kisemlős terjedést elősegítő szerepének teóriáját erősíti.

A kisemlős lyuksűrűség becslés egy viszonylag jól használható módszer az egér- és pocokfajok állományváltozásainak nyomon követésére (Márton és Heltai 2015), azonban az állományméret pontos becslésére csak korlátozottan alkalmas (Liro 1974), melyet Mackin-Rogalska et al. (1986) vizsgálata is alátámaszt. Lengyelországban egy hektáros mintaterületen minden pocokvárat megjelöltek és feljegyeztek, majd vízzel árasztották el a járatokat és megszámolták a menekülő egyedeket. Az egy pocokvárhoz tartozó egyedszám és a kijáratok száma statisztikailag igazolható pozitív kapcsolatot mutatott, az egy egyedre eső lyuk darabszám magas szórása mellett. A lyukszámlálás minél pontosabb létszámbecslésre történő adaptálása a gyakorlati végrehajtóknak idő- és költséghatékony eljárást jelenthet a kezelések során (Lisická et al. 2007, Márton és Heltai 2015).

A vizsgálat összegzéseként elmondható, hogy a fás, cserjés szegélyeknek a nagytáblás mezőgazdasági környezetben jelentős szerepe lehet a kisemlős életközösségek fennmaradásában, valamint azok populációinak aggregálódásában. Az a hipotézis, miszerint a növénytermesztés szempontjából kártevő rágcsálók a szegélyekből terjednek be a múvelt területekre, nem nyert egyértelmű megerősítést, sőt többségében annak ellentmondó eredményt kaptunk. A szegélyeknek a kisemlősökön keresztül a növénytermesztésre gyakorolt közvetett hatásának pontosabb megítéléséhez további vizsgálatok szükségesek, melyek hosszú időtartamon keresztül, 
többféle táblaméretet, kultúrnövény fajt és művelési módot foglalnak magukba.

\title{
KÖSZÖNETNYILVÁNÍTÁS
}

\author{
Köszönettel tartozunk a földhasználóknak, Jászfényszaru Város \\ Önkormányzatának, főképpen Török Imrének, továbbá Győri Ernőnek és \\ ifjabb Győri Ernőnek a mintaterületek biztosításáért.
}

\section{IRODALOM}

Aschwanden, J., Holzgang, O., Jenni, L. (2007): Importance of ecological compensation areas for small mammals in intensively farmed areas. Wildlife Biology 13: 150-158. DOI: 10.2981/09096396(2007)13[150:IOECAF]2.0.CO;2

Ángyán J., Menyhért Z. (2004): Alkalmazkodó növénytermesztés, környezet- és tájgazdálkodás. Szaktudás Kiadó Ház, Budapest. 765 p.

Bayne, E. M., Hobson, K. A. (1998): The effects of habitat fragmentation by forestry and agriculture on the abundance of small mammals in the southern boreal mixedwood forest. Can. J. Zool. 76: 62-69 (1998). DOI: 10.1139/z97-171

Byers, C. L., Steinhorst, R. K., Krausman, P. R. (1984): Clarification of a technique for analysis of utilization-avability data. - Journal of Wildlife Management, 48 (3): 1050-1053. DOI: http://dx.doi.org/10.2307/3801467

De la Pena, N. M., Butet, A., Delettre, Y., Paillat, G., Morant, P., Le Du L., Burel, F. (2003): Response of the small mammal community to changes in western French agricultural landscapes. Landscape Ecology 18: 265-278. DOI: 10.1023/A:1024452930326

Faragó S. (2006): Élőhely-gazdálkodás mezei területeken, különös tekintettel a gyepgazdálkodásra. Gyepgazdálkodási Közlemények 4: 13-24.

Fisher R. A. (1922): On the interpretation of $\chi 2$ from contingency tables, and the calculation of P. Journal of the Royal Statistical Society 85: 87-94. DOI: http://dx.doi.org/10.2307/2340521

Heltai M. (2014): Élőhelyfejlesztés mezőgazdasági területeken: Szent István Egyetem, Vadgazda Mérnöki Szak, Jegyzet vadgazda mérnöki szakos hallgatók részére. Gödöllő pp. 1-111.

Heske E. J. (1995): Mammalian abundances on forest-farm edges versus forest interiors in southern illinois: Is there an edge effect? Journal of Mammalogy, 76 (2): 562-568. DOI: 10.2307/1382364

Ivány K., Kismányoky T., Ragasits I. (1994): Növénytermesztés. 3., átdolgozott kiadás. Mezőgazda Kiadó, Budapest, 377 p.

Jacob J. (2003): Short-term effects of farming practices on populations of common voles. Agriculture, Ecosystems and Environment 95: 321-325. DOI: 10.1016/S0167-8809(02)00084-1

Jacobs J. (1974): Quantitative measurement of food selection. A modification of the forage ratio and Ivlev's electivity index. Oecologia, 14: 413-417. DOI: $10.1007 / B F 00384581$

Klein Á. (2007): Bagolysors, A Gyöngybagolyvédelmi Alapítvány félévente megjelenő kiadványa. II. évfolyam 1. szám-2007. Gyöngybagolyvédelmi Alapítvány, Gyömrő. 19 p. 
Kosztka M. (2010): Mezőgazdasági infrastruktúra alapjai 1. A mezőgazdasági infrastruktúra és a mezőgazdasági utak. MGIN1 modul, Nyugat-magyarországi Egyetem, Geoinformatikai Kar, Székesfehérvár, $21 \mathrm{p}$.

Lagos, V. O., Contreras, L. C., Meserve, P. L., Gutiérrez, J. R., Jaksic, E. M. (1995): Effects of predation risk on space use by small mammals: a field experiment with a Neotropical rodent. Oikos 74: 259-264. DOI: https://www.jstor.org/stable/3545655

Liro A. (1974): Renewal of Burrows by the Common Vole as the Indicator of its Numbers. Acta Theriologica VOL. 19, 17: 259-272. DOI: 10.4098/AT.arch.74-19

Lisická, L., Losík, J., Zejda, J., Heroldová, M., Nesvadbová, J., Tkadlec, E. (2007): Measurement error in a burrow index to monitor relative population size in the common vole. Folia Zool. -56 (2): 169-176.

Mackin-Rogalska R., Adamczewska-Andrzejewska K., Nabagło L. (1986): Common vole numbers in relation to the utilization of burrow systems. In: Acta Theriologica, 31 (2) 17-44. p. DOI: 10.4098/AT.arch.86-2

Márton M., Markolt F., Szabó L., Heltai M. (2014): Niche segregation between two medium-sized carnivores in a hilly area of Hungary. Annales Zoologici Fennici, 51: 423-432. DOI: $\underline{10.5735 / 086.051 .0503}$

Márton M., Heltai M. (2015): Kisemlősök állománysűrűségének vizsgálata különböző élőhelyegyüttesekben. Vadbiológia 17. kötet: 78-89.

Márton M., Heltai M. (2016): Kisemlős populációk vizsgálata a Börzsöny déli oldalán. Természetvédelmi Közlemények 22, pp. 73-83, 2016.

Newsome A. E. (1969): A population study of house-mice temporarily inhabiting a South Australian wheatfield. Journal of Animal Ecology 1969 Vol.38 pp. 341-359. DOI: $10.2307 / 2775$

Németh Cs. (2014): Kisemlős közösségek vizsgálata a Lajta project erdősávrendszerében. Magyar Apróvad Közlemények 12. 275-356, 2014.

Pinke Gy. (1999): Veszélyeztetett szegetális gyomnövények és fenntartásuk lehetőségei európai tapasztalatok alapján. Kitaibelia IV. évf. 1. szám: 95-110.

Radics L. (2010): Fenntartható szemléletű szántóföldi növénytermesztéstan 1. Agroinform Kiadó, Budapest, $700 \mathrm{p}$.

Reiczigel J., Harnos A., Solymosi N. (2010): Biostatisztika nem statisztikusoknak. Pars Kft., Nagykovácsi, $462 \mathrm{p}$.

Sekgororoane, G. B., Dilworth, T. G. (1995): Relative abundance, richness, and diversity of small mammals at induced forest edges. Can. J. Zool. 73: 1432-1437. DOI: 10.1139/z95-168

Silva, M., Hartling, L., Opps, S. B. (2005): Small mammals in agricultural landscapes of Prince Edward Island (Canada): Effects of habitat characteristics at three different spatial scales. Biological Conservation 126 (2005) 556-568. DOI: 10.1016/j.biocon.2005.07.007

Stenseth, N. C., Leirs, H., Skonhoft, A., Davis, S. A., Pech, R. P., Andreassen, H. P., Singleton, G. R., Lima, M., Machang'u, R. S., Makundi, R. H., Zhang, Z., Brown, P. R., Shi D., Wan, X. (2003): Mice, rats, and people: the bio-economics of agricultural rodent pests. Front Ecol Environ 2003; 1(7): 367-375. DOI: 10.1890/1540-9295(2003)001[0367:MRAPTB]2.0.CO;2 